\title{
Study on the Depiction of the Image of Free Women in The Captain's
}

\section{Daughter}

\author{
Zhang Yi \\ Xi'an Fanyi University, Xi'an 710105, China \\ 873667126@qq.com
}

Key words: Pushkin; The Captain's Daughter; Maria

\begin{abstract}
In Pushkin's novel The Captain's Daughter, a major part of this fiction was spent on the depiction of a traditional woman Maria's pursuit of freedom of life and love and her life experience that she finally won freedom after defeating chains. By doing so, the desire for free life and the great willpower of modern women was manifested and also the attachment of women and progressive thinking of Pushkin was revealed. With elaborate analysis of the era-characterized, unique and beautiful character of Maria, Pushkin's appreciation of free women is uncovered in this study. Although without splendid words and plots filled with ups and downs, the novel vividly describes the living conditions of Russian people in $18^{\text {th }}$ century, at that time the freedom of people, especially women, were fettered. That means people has to fight for their freedom, among which resists of women were more common, and this phenomenon has drawn wide-range attention from all walks of life. With only 80,000 words, The Captain's Daughter is a medium-length novel. However, as the last work of Pushkin, it profoundly portrays an important farmer's revolt in $18^{\text {th }}$ century's Russia from all sides. Also in this novel, there is a group of females who are bravely fighting for freedom, with full and mature souls and unshakable faith, they are bold but not reckless as their western counterparts, reserved but not dull as the western females, they have their own ways of struggle. These images laid foundation for the depiction of revolting farmers in later Russian history.
\end{abstract}

\section{Introduction}

Having been exiled by twice and died after a duel, the unyielding fighter Pushkin was born and raised in a declining aristocrat family where a tradition of reading literary was upheld. Pushkin received education from French teacher at an early age, therefore he could poetize in French as early as 8. With an enormous collection of books at home, frequent contacts with literati and folktales he heard from the nanny, this inspired in him a big interest in folk culture and made him acquainted with Russian culture at a very young age. After years of study and writing, Pushkin reached his pinnacle of his career around 1830, namely the Autumn of Pohl Gino (refer to the peak time of a writer), writing out series of popular works such as Eugene Onegin, Anthology of Berkin's Novels, The Stingy Knight, Mozart and Salieri, A Feast in Time of Plague, The Stone Guest. Also at that time, Pushkin formed his own style. After leaving for Saint Petersburg for his job in Ministry of Foreign Affairs, he continued to prolong his golden time by creating famous fictions including The Bronze Horseman, The Fisherman and His Wife, and The Queen of Spades.

InThe Captain's Daughter, peter Grineff, the hero of the novel, born and raised in a family where his father expected him to join in army when he grow up. So, years later, "With his parents' 
blessing, Peter set out for distant Orenburg, in the company of his faithful servant, Savelitch.The trip was not without incident. One night the travelers put up at Simbirsk. There, while his man went to see about some purchases, Peter w as lured into playing billiards with a fellow soldier, Zourin, and quickly lost one hundred roubles. Toward evening of the following day the young man and Savelitch found themselves on the snowy plain with a storm coming up. As darkness fell the snow grew thicker, until finally the horse s could not find their way and the driver confessed that he was lost. They were rescued by another traveler, a man with such sensitive nostrils that he was able to scent smoke from a village some distance away and to lead them to it. The three men and their guide spent the night in the village. The next morning Peter presented his hare skin jacket to his poorly-dressed rescuer.”(The Captain's Daughter) During serving in army, peter gradually fell in love with Maria, the captain's daughter. Unfortunately their love was strongly objected by Maria's father,Captain Mironoff. Just then, a farmer's revolt led by Pougatcheff broke out and the insurgent peasants soon sacked the Bailogorsk fortess, the couple of captain was hanged and peter was spared. It's also at that time, the sergeant Shvabrin, who was the captain's trusted assistant but finally deserted to the rebel army, want to kill peter and forcibly occupy Maria. Thankfully, "From Savelitch he learned that the servant had recognized Pougatcheff as the man to whom he had given his hareskin coat months before." Freed by Pougatcheff, peter was finally able to marry Maria after a good deal of sufferings. But not for long, after the falling of revolt, peter was sentenced to exile in Siberia in charge of intimidate relationship with Pougatcheff. Witnessing the unjustly treatment of her husband, Maria determined to visit the queen as the daughter of the late captain. Having learned of the whole process, the queen freed them peter and the couple's suffer finally came to an end. Based on the depiction of distinctive characters, the novel eulogizes the kindness and integrity of human beings.

\section{Women's Shackles in The Captain's Daughter}

The $19^{\text {th }}$ century had witnessed the booming and quick mature of capitalism, on the contrary, Russia was still under the control of the feudalist and corrupted Czar government. With great development registered in revolution force and people's ever-growing desire for a better life, Maria, a captain's daughter who risked everything for love, is actually a representative of Russian people who yearned for dissimulating discrimination, sweeping obsolete concepts and upholding female rights.

Right from the start, Maria and peter's love was strongly against by the captain. Although peter has submitted to him a letter with the young man's resolution and dueled with Shvabrin, it didn't change the captain's mind and he went on forcing Maria to marry his staff sergeant. In spite of the obstructions of the captain and threat of Shvabrin, Maria and peter had remained adhered to each other. However, throughout Maria's pursuit of love, most of her tortures came from the improper emphasis on parent's view of marriage at that time.

It's saidthat God created men and women in light of the continuous development of human beings. Expect for biological differences, women are always defined as an affiliation to men in conventional thinking. Boasting of physical advantages, males play much more essential roles in production process, which in turns grants them absolute dominance in this section. And this in a sense assures the dominant roles of males in society. Therefore, a lady can do nothing without permission from his father, or his husband. Back into this novel, when her love affair was thwarted by her father, Maria's actions was consistently bounded by women's traditional ideas. And this intense collision of ideas made her hesitate to stand by her beloved husband when she was stuck in dilemma.

After the overturn of the famer's revolt, be told on by Shvabrin in terms of the friendship with 
Pougatcheff and leaving Orenburg without any permission, peter was arrested and finally condemned to life-long exile in the wild Siberia and cannot visit home. Witnessing the unjustly treatment of her husband, Maria determined to try any possible ways to save her husband. As the daughter of the late captain, Maria finally made it to visit the queen and told her all of their tortures and unyielding love all along the way. Moved by Maria's sincere and repeated quests, the Queen finally forgave peter. And Maria and peter's long-term suffering eventually came to an end. At that time, female has no rights to speak of, therefore, Maria's brave and determined action is also a miniature of the rising female consciousness of society.

\section{Rise of Free Women in The Captain's Daughter}

Since their interests were posed threats, revolt from millions of private households from the bottom-up is inexcusable for the nobility and upper classes. With a sensitive and kind heart, Pushkin could place himself in that situation to get a read on their pains, and this in turn made him considerate of their revolt. In this connection, Maria, the heroine of this novel, is a representative of Pushkin in terms of thinking and ideas. In the design of a real free woman's image, Pushkin successfully combined his own thoughts and views with the current social reality of Russia.

In this novel, characters with varying and distinctive personalities and from different classes and backgrounds were created. Although each of them is quite unique in respects, they share one thing in common, namely the pursuit of a free life. Among them, peter and Pougatcheff impressed us most, and Maria's bravery for seeking happiness and sacrifice and fight for love also moved us. As a free woman's image, Maria upholds a loyal view of love. At that time, affected by the surroundings and traditional ideas, it's believed that fathers enjoy the supremacy of arranging their daughters' marriage. However, this outdated idea and the malformed view of marriage it created directly derogated the daughters' liberty of marriage. In face of father's disapproval and contempt, Maria didn't yield to his father's opinionated arrangement nor to conventional ideas when she was encountered with crucial choices. The boldness of sacrificing life for love manifests her advanced view of love of free love and free marriage. Knowing that peter is the love of her life, Maria screwed up her courage to embrace the love, protect it from great hardships and finally step into marriage without any withdrawal behaviors.

With regard to the depiction of Maria's criteria of social kindness and evil, Pushkin added his dissatisfaction of systems and cordial abhorrence of the corrupted government to it, and this in turn made Maria a woman stubbornly believing in freedom.

Despite the fact that Maria is not the leading character, Pushkin sill spent a lot of effort to make the heroine lifelike. With a strong faith in independence and freedom , she kept adhered to her lofty moral quality amid great difficulties. No matter of father's thwart or unjust treatment of her husband, Maria made the right option in front of the crossroad based on her kindness and honesty. This fully embodies her judge and persistence of benevolence and kindness.

\section{Conclusion}

Fully devoted herself to love, Maria is a representative of free female characters in $19^{\text {th }}$ century's Europe. The bravery and perseverance in Maria's pursuit of love reflected not only the cruel social reality but also author's appreciation and encouragement. Although still limited to some extent, Maria is one of the most successful and shining example of free women images . 


\section{References:}

[1] Zheng yanhong: Study on the Chivalry in The Captain's Daughter[J].Journal of PLA University of Foreign Languages,2010:1.

[2] Wu Xuesong: Study on the Features of Character Portray in The Captain's Daughter[J].Journal of Jiamusi University,2010:3.

[3] Ni Siran, Chang Hanwen. Pursuing Freedom and Independence of Personality and Demonstrating Noble Human Ideals-A Study on Pushkin's Value of Life from the Female Characters of His Novels[J].Innovation,2010:34.

[4] Li Yulian, Zhu Yunfang; Study on the Free Women Character in $19^{\text {th }}$ Century's Russian Literary Works[J].Journal of Chengde Normal University,2011:24.

[5] Feng Fang, Zhang Chi. Study on the Free Women Character in The Captain's Daughter[J].Journal of Language Planing, 2014: 4.

[6] Li Junshen: From Pushkin to Scoot-Literary Creation Based on History[J]. Daizongxuekan,1999:1. 